\title{
Living between land and water - structural and functional adaptations in vegetative organs of bladderworts
}

\author{
Markus S. Reut (D) Piotr Świątek (D) \\ Vitor F. O. Miranda $(\mathbb{D} \cdot$ Bartosz J. Plachno $(\mathbb{D}$
}

Received: 12 October 2020 / Accepted: 19 March 2021 / Published online: 19 April 2021

(C) The Author(s) 2021

\begin{abstract}
Aims The carnivorous Utricularia (Lentibulariaceae) has an anatomically simple and seemingly rootless vegetative body. It occupies a variety of wetlands and inland waters and shows a broad range of life forms. Here, we aimed to elucidate structural and functional traits in various hydric conditions. Furthermore, we intended to evaluate morpho-anatomical adaptations in correlation with life forms.

Methods Morpho-anatomical characteristics typical for hydrophytes of all life forms were investigated by light microscopy on 13 Utricularia taxa, compared to one Pinguicula and two Genlisea taxa, and assessed by multivariate analyses.

Results Vegetative structures of Utricularia and Genlisea showed reduced cortical, supporting, and
\end{abstract}

Responsible Editor: Hans Lambers.

M. S. Reut $(\bowtie) \cdot$ B. J. Płachno $(\bowtie)$

Department of Plant Cytology and Embryology, Institute of Botany, Faculty of Biology, Jagiellonian University in Kraków, Gronostajowa 9 St, 30-387 Kraków, Poland

e-mail: info.reut@gmail.com

e-mail: bartosz.plachno@uj.edu.pl

P. Świątek

Institute of Biology, Faculty of Natural Sciences, University of Silesia in Katowice, 9 Bankowa St.ID 40-007 Katowice, Poland

V. F. O. Miranda

School of Agricultural and Veterinarian Sciences, Department of Applied Biology, Laboratory of Plant Systematics, UNESP - São Paulo State University, Campus Jaboticabal, Jaboticabal CEP 14884-900 SP, Brazil vascular tissues. With increasing water table, leaves were thinner, and narrower or dissected, and submerged organs tended to contain chloroplasts in parenchymatic and epidermal cells. In some main stolons, an endodermis with Casparian strips was visible. Large gas chambers, including a novel 'crescent' and a special 'hollow' aerenchyma pattern, were found in amphibious to freefloating taxa.

Conclusions The evolutionary transfer of carnivory from aerial to subterranean organs in Genlisea, and even more in Utricularia, coincides with a highly simplified anatomy, which is adapted to a broad variety of hydric conditions and compensates for structural innovations in the uptake of nutrients.

Keywords Utricularia $\cdot$ Lentibulariaceae . Hydrophyte $\cdot$ Carnivorous plants $\cdot$ Life forms . Aerenchyma $\cdot$ Casparian strips $\cdot$ Anatomy

\section{Introduction}

\section{Life forms of hydrophytes}

Hydrophytes are plants living "in water or on a substrate that is saturated at a frequency and duration during the growing period sufficient to affect plant occurrence" (Tiner 2017). Water plants constitute about $1-2 \%$ of the angiosperms today, while vascular hydrophytes (macrophytes) evolved from terrestrial plants of hundreds of families and genera at several points in time (Cook 1999; Chambers et al. 2008). 
The life forms (habits) of aquatic plants range from terrestrial but occasionally inundated taxa, with anchorage in the substrate and with leaves and reproductive organs exposed to the air, to unattached, free-floating taxa with all parts under water. Between the extremes, gradually different forms exist, contingent upon water regimes and adaptive responses of the plants to environmental changes such as flooding and unflooding, precipitation, or evaporation (cf. Sculthorpe 1967; Braendle and Crawford 1999; Tiner 2017). Many hydrophytes have adapted to various habitats and hence show more than just one life or growth form (cf. Sculthorpe 1967; Cook 1999).

\section{Classification of hydrophytes}

Authors engaged in the research of carnivorous plants and the Lentibulariaceae in particular (e.g. Taylor 1989; Guisande et al. 2007; Reut and Płachno 2020) designate most species within the Lentibulariaceae as "terrestrials", although the majority colonizes wet, waterlogged or temporarily submerged habitats. According to Taylor (1989), "terrestrial" plants are those flowering when the soil is humid or saturated but being submerged in wet periods, which coincides with Cook's (1999) definition of 'tenagophytes'. Taylor (1989) delimits "terrestrials" from affixed aquatics and (freely) suspended (inflated) aquatics but in some instances also from subaquatics. Affixed aquatics are mostly anchored in the substrate (Guisande et al. 2007) and possibly represent a transition towards suspended (free-floating) hydrophytes (Jobson et al. 2003). Subordinating subaquatic in "terrestrial" habits (e.g. Guisande et al. 2007) or subaquatic in affixed aquatic habits (e.g. Jobson et al. 2018) leads to results which are difficult to compare. This attempt of a classification of life forms in carnivorous plants does not seem to be suitable for a classification of hydrophytes in general and needs to be adjusted.

In the current paper, we follow a simple classification of habits of wetland and aquatic plants as outlined by Sculthorpe (1967) and Hutchinson (1975), differentiating between 'anchored hydrophytes' (encompassing 'emergent hydrophytes', 'floating-leaved hydrophytes', and 'submerged hydrophytes') and 'free-floating hydrophytes'. However, since 'amphiphytes' are adapted to a terrestrial as well as a (periodically) submerged life, i.e. to aerobic and anaerobic conditions, we rank this group among anchored hydrophytes. They are often found in the transitional zone between land and water where flooding and unflooding occur (Braendle and Crawford 1999; Crawford 2008). Extending the scope of hydrophytes by adding amphiphytes enables the identification of ecological and evolutionary transects (i.e. various grades and combinations of morphological and anatomical specializations) within hydrophytic plants, and the concurrent delimitation of this group from purely terrestrial plants (Barrett et al. 1993).

Morpho-anatomical characters

Early anatomical works on hydrophytes provide insights into structural characteristics of species and genera across various plant families (e.g. Schenck 1886; Arber 1920). In his book on aquatic vascular plants, Sculthorpe (1967) connects morpho-anatomical traits with physiological and functional aspects. Experimental and observational studies, mainly at the species level, led to the conclusion that the life in a transitional zone between land and water, and in fluctuating water conditions entails a variety of adaptive responses, and hence a greater phenotypic plasticity, especially in amphibious and emergent hydrophytes (Barrett et al. 1993; Crawford 2008; Lusa et al. 2011). In these groups, heterophylly is widespread, exhibiting submerged and aerial leaf forms adapted to the respective milieu (Sculthorpe 1967; Mommer et al. 2005; Li et al. 2019). In the relatively stable and homogeneous environment of the water column, however, the diversification of obligate hydrophytes is generally low (Barrett et al. 1993; Hidalgo et al. 2015). Overall, hydrophytes show heterogeneous combinations of morphological, anatomical, and functional traits (Table 1) that differ from those of strictly terrestrial plants.

Comparing species of various life forms within one genus may uncover adaptations to habitats and hence also evolutionary aspects rather than just phenotypic responses to changes in the environment. However, to date, a comparative morpho-anatomical study on a hydrophytic plant genus with a broad range of life forms is missing. One reason may be that only few aquatic genera offer a large variety of life forms (cf. Cook 1999). One of these is the carnivorous Utricularia L.

\section{Lentibulariaceae}

Members of the bladderwort family (Lentibulariaceae: Lamiales) with its three genera Pinguicula L., Genlisea A.St.-Hil. and Utricularia L. are among the 
Table 1 Common morphological and anatomical characters and their functions in herbaceous hydrophytes

\begin{tabular}{|c|c|c|}
\hline & Morphological / anatomical adaptation & Function \\
\hline 1) & Reduced or absent roots in some (submerged) species & $\mathrm{BIO}$ \\
\hline 2) & $\begin{array}{l}\text { Tendency to develop narrow leaves (submerged form) or dissected leaves (in } \\
\text { several submerged or free-floating aquatics) increasing the ratio of surface } \\
\text { to volume }\end{array}$ & ABS, FLE, LIG \\
\hline 3) & $\begin{array}{l}\text { Thin leaves without palisade parenchyma, and with reduced or no } \\
\text { mesophyll, losing dorsiventrality }\end{array}$ & FLE, LIG \\
\hline 4) & Epidermis of submerged organs/leaves with chloroplasts & LIG \\
\hline 5) & Delicate submerged organs with a thin cuticula & $\mathrm{ABS}$ \\
\hline 6) & Reduced xylem elements & $\mathrm{BIO}$ \\
\hline 7) & $\begin{array}{l}\text { Prominent intercellular spaces (between spongy parenchyma in leaves) or } \\
\text { lacunar / aerenchymatous anatomy }\end{array}$ & GAS \\
\hline 8) & $\begin{array}{l}\text { Occurrence of hydropotes or glandular types of trichomes in the epidermis, } \\
\text { e.g. in submerged species of Potamogeton, Ceratophyllum, and } \\
\text { Cryptocoryne }\end{array}$ & ABS \\
\hline 9) & Reduced or absent supporting tissue (sclerenchyma, collenchyma) & FLE \\
\hline 10) & $\begin{array}{l}\text { Limitation of the vascular strand to a central cylinder in roots (and stems); } \\
\text { endodermoid layer, channelizing the flow of water through reduced xylem }\end{array}$ & $\mathrm{BAR}, \mathrm{BIO}$ \\
\hline 11) & $\begin{array}{l}\text { Reduction, inactivity, or absence of stomata (especially in submerged } \\
\text { leaves); in some plants replaced by secretory structures }\end{array}$ & BIO, STO \\
\hline 12) & Development of adventitious roots & STA, ABS \\
\hline
\end{tabular}

Abbreviations of functions: $\mathrm{ABS}=$ Enhancement of absorption of nutrients, and dissolved $\mathrm{CO}_{2}$ and $\mathrm{O}_{2}$; GAS = Passage for an increased diffusion of gases, responding to gaseous pressure; buoyancy; BAR = Barrier to restrict radial oxygen loss (ROL) to the soil; $\mathrm{BIO}=$ Optimization of biomass investment (alternative structures for the uptake or transport of nutrients and dissolved gases); FLE = Flexibility in water movements; LIG = Enhancement of the collection of light in lower light conditions and in every organ orientation; STA = Stabilization of the plant (rosette) position in the water; STO = Redundancy of stomata (gas exchange in the air) in submerged organs; hydathodes for guttation (water secretion by root pressure) on floating leaves

Summarized from overviews by Sculthorpe (1967), Wetzel (1988), Wiegleb (1991), Jung et al. (2008), Colmer et al. (2011), Krähmer (2016), and Tiner (2017)

most interesting herbaceous angiosperms because of their carnivorous nature, unique vegetative bodies, small genome sizes, and several more biological peculiarities (cf. Ibarra-Laclette et al. 2013; Rutishauser 2020; Silva et al. 2020a).

Rosulate and rhizomatous growth forms are generally found in terrestrial or amphibious species of the Lentibulariaceae, while stolonifery occurs within all habits. In the current paper, we use the terms 'rhizome' and 'stolon' group-specifically. Both are generally horizontally growing shoots, while rhizomes tend to be shorter, often having storage function and giving rise to roots. Stolons are considered to have longer internodes. 'Anchor stolons' ('rhizoids', Taylor 1989) of several Utricularia species are assigned to unbranched and much shorter organs that grow geotropically positive and generally into the soil (Reut and Płachno 2020).

The rosulate butterworts (Pinguicula) contain around 100 species of which most of them are mesophytes, amphiphytes and lithophytes, and only a few are true epiphytes (Fleischmann and Roccia 2018; Casper 2019). Insects are trapped on the foliage leaves of homophyllous butterworts above ground throughout the year, while heterophyllous species are effectively carnivorous only during wet periods (e.g. Legendre 2000; Fleischmann and Roccia 2018). Pinguicula species have rhizomes (Casper 2019) or short stems (Legendre 2000), and few produce runner stolons.

The corkscrew plants (Genlisea) comprise 31 species of amphiphytes and few emergent hydrophytes (Fleischmann 2012, 2018; Silva et al. 2020b). Genlisea is considered being heterophyllous, having non-carnivorous rosettes of green leaves above ground and subterranean "rhizophylls" that function like an eel-trap (Reut 1993; Fleischmann 2018; Płachno and Muravnik 2018). Genlisea shows short vertical stems or horizontal rhizomes (Fleischmann 2018). Since the rhizomes in G. repens are elongated (Reut 1993), they will hereafter be called stolons in accordance with Fleischmann (2018). 
Finally, the bladderworts (Utricularia) are the most diverse within the Lentibulariaceae. They consist of about 240 species and show the widest range of life forms within the family, from mesophytes to freefloating aquatics, in addition to rheophytes, lithophytes, and epiphytes (cf. Guisande et al. 2007; Jobson et al. 2018; Jobson and Baleeiro 2020). Like Genlisea, "terrestrial" Utricularia species have leaves for photosynthesis and subterranean leaf-like organs for carnivory. In Utricularia, the prey is actively captured by tiny suction bladders, functioning like a mousetrap, while the tubular trap of Genlisea is considered being passive. However, abundant water is required for an effective operation of both trap types (Guisande et al. 2007; Jobson et al. 2018; Płachno et al. 2019a, b). Most species of Utricularia are stoloniferous (Taylor 1989; Jobson et al. 2003). The term "stolon" has established in Utricularia and prevails for reasons of consistency (Taylor 1989), also because in some species it grows above ground and up to several meters in length.

Anatomy of vegetative organs in the Lentibulariaceae

Early anatomical examinations of vegetative parts of carnivorous plants were done e.g. by Kamieński (1891), Lang (1901) and Merl (1915), but they largely failed to imply comparative discussions on functional aspects in a broader context of e.g. carnivory or adaptations to aquatic habitats. Later anatomical studies on vegetative organs in the Lentibulariaceae were mainly focusing on trap tissues (e.g. Lloyd 1942; Płachno et al. 2014; Płachno et al. 2017) and the functional ultrastructure of digestive glands (e.g. Płachno and Jankun 2004; Płachno et al. 2019a). Most recently, Płachno et al. (2020b) described structures of tubers in one Genlisea and two Utricularia species showing adaptation to abiotic stress (e.g. seasonal drought or fire). Reut and Płachno (2020) examined the anatomy of stolons, bladder stalks and leaves of $U$. dichotoma sensu lato clones, originating from five amphibious to emergent populations of Australia and New Zealand, and found simple and lacunate characters, which are basically homogenous throughout the subterranean/submersed organs and across the sources.

Aims of the study

In the current study, we use Utricularia (Lentibulariaceae) as model genus to investigate differences and commonalities of morpho-anatomical characters between species of several hydrophytic life forms, as this genus yields probably the greatest richness of habits amongst hydrophytes. We aim to elucidate by which structural means Utricularia handles water, nutrients, and gases in various hydric conditions. By applying multivariate analyses, we assess the clustering of life forms and the grade of adaptations to the level of submergence, in correlation to combinations of morpho-anatomical characters of vegetative organs of several amphibious, submerged, and free-floating taxa of Utricularia and chosen taxa of Pinguicula and Genlisea. Results are discussed in relation to functional aspects of traits, the carnivorous syndrome, and the evolution of the Lentibulariaceae.

\section{Materials and methods}

Plant material and preparation

In our morpho-anatomical investigation, we selected a total of 16 species from the Lentibulariaceae genera Pinguicula, Genlisea and Utricularia (see Table 2 for a full description, including taxonomic ranking, growth form and sources).

The plant material was studied with respect to several morpho-anatomical characters as outlined in Table 1. Examinations were performed on leaves, roots (Pinguicula only), trap stalks, and several types of stolons (where present). The anatomy of leaves was investigated on P. gigantea, G. hispidula, U. volubilis, $U$. paulineae, U. uniflora, U. delicatula, and U. stygia. Detailed data of all investigated Lentibulariaceae species with traits of leaves, stolons, roots, anchor stolons, and trap stalks is provided in the Supplementary Information (Online Resource) 1.

Plant samples used for light microscopy were fixed in a mixture of $2.5 \%$ glutaraldehyde and $2.5 \%$ formaldehyde in a $0.05 \mathrm{M}$ cacodylate buffer (Sigma; pH 7.2) overnight or for up to four days. After fixation, the material was washed three times in a $0.1 \mathrm{M}$ sodium cacodylate buffer followed by post-fixation in $1 \%$ osmium tetroxide solution at room temperature for $1.5 \mathrm{~h}$. The samples were dehydrated in graded ethanol series to $95 \%$, infiltrated and embedded using an epoxy embedding medium kit (Fluka). After polymerisation at $60^{\circ} \mathrm{C}$, sections were cut using a Leica Ultracut UCT ultramicrotome. Semi-thin sections $(0.9-1.0 \mu \mathrm{m}$ thick) were prepared and stained with aqueous methylene blue / 
Table 2 Plant material used for anatomical examinations

\begin{tabular}{|c|c|c|c|}
\hline $\begin{array}{l}\text { Genus } \\
\text { Subgenus } \\
\text { Section }\end{array}$ & Species & $\begin{array}{l}\text { Habit, } \\
\text { growth }\end{array}$ & Source \\
\hline \multicolumn{4}{|l|}{ Pinguicula } \\
\hline \multicolumn{4}{|l|}{ Isoloba } \\
\hline Agnata & Pinguicula gigantea Luhrs & $\mathrm{t}(1)$, sto & Ex origin Oaxaca, Mexico ${ }^{1} *$ \\
\hline \multicolumn{4}{|l|}{ Genlisea } \\
\hline \multicolumn{4}{|l|}{ Genlisea } \\
\hline \multirow[t]{2}{*}{ Genlisea } & Genlisea hispidula Stapf & $\mathrm{a}, \operatorname{ros}$ & Ex origin Africa ${ }^{1} * *$ \\
\hline & Genlisea repens Benj. & a, sto & Ex origin South America ${ }^{2} * *$ \\
\hline \multicolumn{4}{|l|}{ Utricularia } \\
\hline \multicolumn{4}{|l|}{ Polypompholyx } \\
\hline Polypompholyx & Utricularia multifida $\mathrm{R} . \mathrm{Br}$. & $\mathrm{a}, \operatorname{ros}$ & Ex origin Western Australia ${ }^{3 *}$ \\
\hline \multirow[t]{5}{*}{ Pleiochasia } & Utricularia volubilis R.Br. & $(\mathrm{e}-) \mathrm{s}, \operatorname{ros}$ & $\begin{array}{l}\text { Ex origin SW Western } \\
\text { Australia } \\
\text { A }_{* *}\end{array}$ \\
\hline & Utricularia paulineae A.Lowrie & a, sto & Ex origin SW Western Australia ${ }^{5 * *}$ \\
\hline & Utricularia oppositiflora R.Br. $\dagger$ & $\mathrm{a}(-\mathrm{e})$, sto & $\begin{array}{l}\text { Ex origin Newcastle, New South } \\
\text { Wales, Australia }{ }^{4 * *}\end{array}$ \\
\hline & $\begin{array}{l}\text { Utricularia dichotoma subsp. aquilonia } \\
\text { R.W.Jobson } \dagger\end{array}$ & a, sto & $\begin{array}{l}\text { Ex origin Katoomba, New South } \\
\text { Wales, Australia }{ }^{1 * *}\end{array}$ \\
\hline & Utricularia tubulata F.Muell. & $\mathrm{f}$ & Ex origin Australia ${ }^{6 * * * *}$ \\
\hline Lasiocaules & Utricularia uniflora R.Br. & a, sto & Ex origin Australia ${ }^{5 * *}$ \\
\hline \multicolumn{4}{|l|}{ Bivalvaria } \\
\hline Australes & Utricularia delicatula Cheeseman & a, sto & $\begin{array}{l}\text { Ex origin Whangamarino wetlands, } \\
\text { New Zealand }{ }^{5 * *}\end{array}$ \\
\hline \multicolumn{4}{|l|}{ Utricularia } \\
\hline Foliosa & Utricularia tricolor A.St.Hil. & a, sto & Araraquara, São Paulo State, Brazil ${ }^{7}$ \\
\hline Utricularia & Utricularia stygia Thor & s, sto & Treboň, Czech Republic ${ }^{8}$ \\
\hline \multirow[t]{2}{*}{ Vesiculina } & Utricularia cucullata A.St.Hil. \& Girard & f, sto & $\begin{array}{l}\text { a) Itirapina, São Paulo State, Brazil; } \\
\text { b) Delfinópolis, Minas Gerais } \\
\text { State, Brazil }^{9}\end{array}$ \\
\hline & Utricularia purpurea Walter & (s-)f, sto & Ex origin unknown ${ }^{4} * * * *$ \\
\hline
\end{tabular}

The taxonomy of genera, subgenera, sections and species follows Cieslak et al. (2005), Fleischmann (2012), Jobson et al. (2018), and Jobson and Baleeiro (2020)

$\dagger$ Treated as U. dichotoma sensu Taylor (1989) in Reut and Płachno (2020), but subsequently underwent taxonomic revision by Jobson and Baleeiro (2020)

Habit of sample (alternative/usual life form in situ in brackets): amphiphyte (a); emergent hydrophyte (e); free-floating (suspended) hydrophyte (f); lithophyte (1); submerged hydrophyte (s); terrestrial plant (t). Growth form: with floats (flo); rosulate (ros); stoloniferous (sto) Sources, ex situ: ${ }^{1}$ Cultivation in the Botanic Garden of Jagiellonian University in Kraków, Poland. ${ }^{2}$ Cultivation in the Department of Plant Cytology and Embryology, Institute of Botany, Jagiellonian University in Kraków, Poland. ${ }^{3}$ Collection of Kamil Pásek, Ostrava, Czech Republic, http://www.bestcarnivorousplants.net. ${ }^{4}$ Collection of Dr. Lubomír Adamec, Institute of Botany of the Czech Academy of Sciences at Treboň, Czech Republic. ${ }^{5}$ Collection of Nigel Hewitt-Cooper, UK, http://www.hccarnivorousplants.co.uk. ${ }^{6}$ Collection of Corin Gardiner, New Zealand. *Grown in humid soil. **Grown in wet to saturated soil. ***Grown under water in an aquarium, anchored in soil. $* * * *$ Grown free-floating

Sources, collected in situ: ${ }^{7}$ Farm near Araraquara, São Paulo State, Brazil; Fazenda Palmeiras, swamp c. 50 m from the road; V.F.O.Miranda et al. 2856. ${ }^{8}$ Near Treboň, Czech Republic. ${ }^{9}$ From two populations: (a) road Itirapina-Brotas, São Paulo State, Brazil; swamp c. $10 \mathrm{~m}$ from the road; V.F.O.Miranda et al. 2859; (b) Delfinópolis, Minas Gerais State, Brazil; flooded area c. $250 \mathrm{~m}$ from the road; V.F.O.Miranda et al. 2877 
azure II (MB/AII) for 1-2 min (Humphrey and Pittman 1974). Additional material was fixed as above, embedded in Technovit 7100 (Kulzer, Germany) and processed as in Lustofin et al. (2020). Sections were examined and photographed using a Nikon Eclipse E400 microscope with a Nikon DS-Fi2 camera and NISElements D 4.00.00 4.0 software (Nikon, Tokyo, Japan) and using an Olympus BX60 microscope with an Olympus XC50 digital camera and cellSens Standard Software (Olympus, Tokyo, Japan).

\section{Multivariate analyses}

To quantitatively evaluate morpho-anatomical characters and their correlation with life forms in the Lentibulariaceae, we selected characters 1-9 from Table 1, as only those provided variability across the chosen taxa. The traits were recorded from 14 species with comparable organs (leaves for the morphological and stolons for anatomical data collection). To visualize how the species can be optimally clustered, if life forms can be suitably grouped, and which morpho-anatomical features contribute most to the groupings, the data dimensionality was reduced through several computing techniques while maintaining the most important information. We created three sets of variables for multivariate analyses on the 14 taxa. Dataset I contained 'life forms' and 'location of stolons' in addition to the morpho-anatomical characters 1-9. The trait 'life forms' was selected to assess correlations of life forms with all other traits. 'Location of stolons' was included in dataset I to evaluate how far the stolon related traits were influenced by the location of the stolons in the respective substrate. In dataset II we excluded 'life forms', and dataset III contained the morpho-anatomical traits only. All biometric traits and their values used in the analyses are presented in Table 3.

We ran a graph-based clustering with BioVinci (BioTuring Inc) version 3.0.9 to calculate the "best fit" dimensionality reduction method with highest Silhouette Score $[-1,1]$. In addition, the tool identified suitable traits supporting the evaluated hierarchical clusters in a decision tree by applying cost complexity pruning criteria such as Gini index and Entropy. The same methods were used when clusters were validated according to life forms ('life form clustering'). We ran Principal Component Analyses (PCA) by exclusion vs. inclusion of pre-processing with scaling, and by applying singular value decomposition (SVD) with imputation to calculate principal components. Some PCA scatter plots were overlayed with vectors (traits), adding information on the correlations of traits (direction of vectors) and the influence of traits (lengths of vectors). PCA statistics were taken from BioVinci (BioTuring Inc) version 1.1.5. The computing and illustration of

Table 3 Biometric traits and their values used in multivariate analyses

\begin{tabular}{|c|c|c|}
\hline & Trait (variable) & Value \\
\hline L) & Life form & $\begin{array}{l}\text { terrestrial plant (1), amphiphyte (2), submerged hydrophyte (4), free-floating } \\
\quad \text { (suspended) hydrophyte (5) }\end{array}$ \\
\hline 0$)$ & Stolon location & $\begin{array}{l}\text { above ground, aerial (1), subterranean, few } \mathrm{mm} \text { to few } \mathrm{cm} \text { in the soil (2), } \\
\text { submersed, few } \mathrm{cm} \text { under water - in soil or floating (3) }\end{array}$ \\
\hline 1) & Anchoring organs & $\begin{array}{l}\text { roots present (1), anchor stolons (rhizoids) present ( } 2 \text { ), } \\
\text { roots/rhizoids absent ( } 3 \text { ) }\end{array}$ \\
\hline 2) & Leaf form & $\begin{array}{l}\text { large-fleshy obovate (1), small spathulate-circular (2), (small) narrow-linear (3), } \\
\text { dissected (4) }\end{array}$ \\
\hline 3) & Leaf thickness & mesophyll layers: > 10 (1), 8-10 (2), 4-7 (3), < 4 (4) \\
\hline 4) & Stolon chloroplasts & none identified (1), in parenchyma (2), in parenchyma and epidermis (3) \\
\hline 5) & Stolon diameter & thickness, in mm: > $0.56(1), 0.41-0.56(2), 0.25-0.40(3),<0.25$ (4) \\
\hline 6) & Stolon xylem & $\begin{array}{l}\text { Xylem tracheary element (vessel), diameter in } \mu \mathrm{m}:>20(1), 14-20(2), \\
<14(3), \text { none identified or xylem lacuna only }(4)\end{array}$ \\
\hline 7) & Stolon intercellular spaces & $\begin{array}{l}\text { nil (1), slight intercellular spaces (2), moderate/extensive intercellular spaces to } \\
\text { wheel-shaped aerenchyma (3), crescent to hollow aerenchyma (4) }\end{array}$ \\
\hline 8) & Stolon external glands & absent (1), present (2) \\
\hline 9) & Stolon supporting tissue & present (1), absent (2) \\
\hline
\end{tabular}


confidence ellipses $(\mathrm{CI}=95 \%)$ of clusters in PCA were done with ClustVis (Metsalu and Vilo 2015).

\section{Results}

Morpho-anatomy of leaves and main stolons

We characterized the anatomical traits of leaves and main/runner stolons (see Table 4 for a full description, including references to figures).
Additional data can be found in Table 5, which was used for multivariate analyses.

\section{Morpho-anatomy of other vegetative organs}

The stoloniferous $P$. gigantea showed adventitious roots arising from a short vertical stem, without branching or root cap, but with unicellular hairs. Vegetative organs of Genlisea and Utricularia did not exhibit external root structures and adventitious roots. Some Utricularia species developed other anchoring organs (so called anchor

Table 4 Summary of morpho-anatomical characters of leaves and stolons

\begin{tabular}{|c|c|c|}
\hline & Leaves (Fig. 1a-e) & Stolons (Figs. 1f-h and 2) \\
\hline Organization & Simple & Simple \\
\hline Cross-section & $\begin{array}{l}\text { Dorsiventral (but circular in trap bearing } U . \text { volubilis } \\
\text { leaves) }\end{array}$ & Circular \\
\hline Epidermis & Uniseriate & Uniseriate \\
\hline Cuticle* & Cuticularized & $\begin{array}{l}\text { Cuticle seemingly thin (e.g. Figs. } 1 \mathrm{f} \text { and g and 2e) } \\
\text { but somewhat thicker in } U \text {. volubilis (Fig. } 2 \mathrm{~d} \text { ) }\end{array}$ \\
\hline Stomata & Stomatous (except for submersed leaves) & No stomata found \\
\hline Glands & $\begin{array}{l}\text { P. gigantea: Stalked and sessile glands } \\
\text { Genlisea and Utricularia: button-like glands }\end{array}$ & $\begin{array}{l}\text { Genlisea and Utricularia: button-like glands abun- } \\
\text { dant (Fig. 2e) with generally one head cell (but } \\
\text { with two head cells in U. breviscapa) }\end{array}$ \\
\hline $\begin{array}{l}\text { Mesophyll (leaf) / } \\
\text { cortex (stolon) }\end{array}$ & $\begin{array}{l}\text { Palisade parenchyma absent. } \\
\text { P. gigantea: prominent water storage tissue } \\
\text { Genlisea and Utricularia: Spongy parenchyma } \\
\text { Intercellular spaces or lacunae present (Fig. } 1 \mathrm{c}-\mathrm{e})\end{array}$ & $\begin{array}{l}\text { Pentagonal to polygonal, thin-walled and unlignified } \\
\text { parenchymatic cells (more irregular cell shapes in } \\
P \text {. gigantea, Fig. 1g). } \\
\text { Intercellular spaces: none (P. gigantea, Fig. 1g), } \\
\text { small (e.g. G. repens, Fig. 1f), or } \\
\text { frequently aerenchymatic (Fig. } 2 \mathrm{a}, \mathrm{c}-\mathrm{i}), \\
\text { predominantly lysigenous } \\
\text { No hypodermis/exodermis found }\end{array}$ \\
\hline Chloroplasts & $\begin{array}{l}\text { P. gigantea: adaxially in mesophyll, abaxially in } \\
\text { patches, and in bundle sheaths; occasionally } \\
\text { with amyloplasts } \\
\text { Genlisea and Utricularia: in spongy parenchyma; in } \\
\text { submerged and free-floating Utricularia species } \\
\text { also in the epidermis (Fig. 1e) }\end{array}$ & $\begin{array}{l}\text { None or very few to numerous in parenchyma; in } \\
\text { some species also in the epidermis (Fig. 2i) } \\
\text { G. repens. Occasionally with amyloplasts (Fig. 1f) }\end{array}$ \\
\hline Vascular tissue & $\begin{array}{l}\text { P. gigantea: bundle shape almost a closed circle, } \\
\text { with } 3 \text { to }>13 \text { lignified xylem tracheary elements } \\
\text { (vessels) scattered towards the centre and } 3 \text { to }>13 \\
\text { phloem groups towards the abaxial side } \\
\text { (Fig. } 1 \mathrm{a}, \mathrm{b} \text { ) } \\
\text { Genlisea and Utricularia: } 1-2 \text { xylem tracheary ele- } \\
\text { ments (vessels) and } 1-3 \text { phloem groups (e.g. } \\
\text { Fig, 1c), but occasionally no xylem found } \\
\text { (Fig. 1d, e) }\end{array}$ & $\begin{array}{l}\text { Ectophloic central cylinder with unlignified pith } \\
\text { cells and without pericycle. } \leq 4 \text { lignified xylem } \\
\text { tracheary elements and } \leq 12 \text { or more phloem } \\
\text { groups (Figs. } 1 \mathrm{f}-\mathrm{h} \text { and } 2 \text { ). Xylem vessels not } \\
\text { found in some stolons of } U \text {. stygia and } \\
U . \text { breviscapa, or central (xylem) lacuna occa- } \\
\text { sionally present (Fig. } 2 \mathrm{a}, \mathrm{g} \text { ). Phloem generally } \\
\text { present but not identifiable in } U \text {. uniflora (Fig. } 2 \\
\text { f). }\end{array}$ \\
\hline Supporting tissue & Absent & $\begin{array}{l}\text { Generally absent, but present internal to parenchyma } \\
\text { sheath / endodermis in G. repens and U. tricolor } \\
\text { (Fig. 1f, h) }\end{array}$ \\
\hline
\end{tabular}

*not conclusively demonstrated by the applied methods 
Table 5 Data matrix of species and their values of biometric traits used in multivariate analyses

Dataset I

Dataset II

Dataset III

\begin{tabular}{|c|c|c|c|c|c|c|c|c|c|c|c|}
\hline \multirow[b]{2}{*}{ Species } & \multirow[b]{2}{*}{$\mathrm{L}$} & \multirow[b]{2}{*}{0} & \\
\hline & & & 1 & 2 & 3 & 4 & 5 & 6 & 7 & 8 & 9 \\
\hline PGI & 1 & 1 & 1 & 1 & 1 & 1 & 1 & 2 & 1 & 1 & 2 \\
\hline GRE & 2 & 2 & 3 & 2 & 2 & 3 & 1 & 2 & 2 & 2 & 1 \\
\hline UVO & 4 & 3 & 2 & 3 & 3 & 2 & 2 & 3 & 3 & 2 & 2 \\
\hline UPA & 2 & 2 & 2 & 2 & 3 & 1 & 3 & 3 & 4 & 2 & 2 \\
\hline UOP & 2 & 2 & 2 & 3 & 3 & 2 & 1 & 2 & 4 & 2 & 2 \\
\hline UDI & 2 & 2 & 2 & 2 & 3 & 3 & 3 & 3 & 4 & 2 & 2 \\
\hline UTU & 5 & 3 & 3 & 3 & 4 & 3 & 3 & 4 & 3 & 2 & 2 \\
\hline UUN & 2 & 2 & 2 & 2 & 3 & 1 & 4 & 3 & 4 & 2 & 2 \\
\hline UDE & 2 & 2 & 2 & 3 & 2 & 1 & 4 & 3 & 3 & 2 & 2 \\
\hline UTR & 2 & 2 & 2 & 2 & 3 & 2 & 2 & 1 & 3 & 2 & 1 \\
\hline UST & 4 & 3 & 2 & 4 & 4 & 2 & 2 & 2 & 3 & 2 & 2 \\
\hline UBR & 5 & 3 & 3 & 4 & 4 & 3 & 1 & 4 & 3 & 2 & 2 \\
\hline UCU & 5 & 3 & 3 & 4 & 4 & 3 & 3 & 3 & 3 & 2 & 2 \\
\hline UPU & 5 & 3 & 3 & 4 & 4 & 3 & 2 & 3 & 3 & 2 & 2 \\
\hline
\end{tabular}

Species (samples): G. repens (GRE); P. gigantea (PGI); U. breviscapa (UBR); U. cucullata (UCU); U. delicatula (UDE); U. dichotoma subsp. aquilonia (UDI); U. oppositiflora (UOP); U. paulineae (UPA); U. purpurea (UPU); U. stygia (UST); U. tricolor (UTR); U. tubulata (UTU); U. uniflora (UUN); U. volubilis (UVO)

Traits (variables, further defined in Table 3): Life form (habit) (L), stolon location (0), anchoring organ (1), leaf form (2), leaf thickness (3), stolon chloroplasts (4), stolon diameter (5), and stolon xylem (vessels / diameter) (6), stolon intercellular spaces (7), stolon external glands (8), stolon supporting tissue (9)

stolons or "rhizoids") with geotropically positive growth (see also Table 5).

In the root of $P$. gigantea, parenchyma was densely packed. Except for $U$. volubilis, all examined trap stalks and the anchor stolon of $U$. multifida showed spacious ('hollow type') aerenchyma, occupying nearly the whole interior of the organ, and leaving only a bridge of parenchyma between the vascular strand and the epidermis.

Anatomy of the central cylinder

The central cylinder was generally bordered by a uniseriate parenchyma sheath in roots and in main stolons (Figs. 1f and 2d, e, g and i), in which an endodermis (Fig. 1h, 2a-c, h) with Casparian strips (Fig. 2b, h) was visible in $U$. tricolor, $U$. oppositiflora, $U$. delicatula, and $U$. stygia. The parenchyma sheath and the thinwalled endodermis with Casparian strips did not differ greatly in shape from cortex parenchyma. In the runner stolon of $P$. gigantea, the sheath structure was less apparent but implied by smaller parenchyma cells irregularly surrounding and interlacing the vascularized central zone (Fig. 1g).

Multivariate analyses

The results of cluster analyses of datasets I-III are presented in Table 6, showing Silhouette Scores, clusters of species, and decisive traits for the branching (clustering of species) for selected dimensionality reduction and clustering methods. A selection of multivariate analyses of datasets I-III is visualized in Fig. 3, illustrating correlations (distances) and clusters of species.

Even though UMAP is not an ideal method for cluster analysis, as the data tend to be uniformly distributed, the separation of two clusters (terrestrial-amphibious and submerged-free-floating) with graph-based clustering of dataset I was distinctive and received support by PCA (Table 6; Fig. 3a). The 

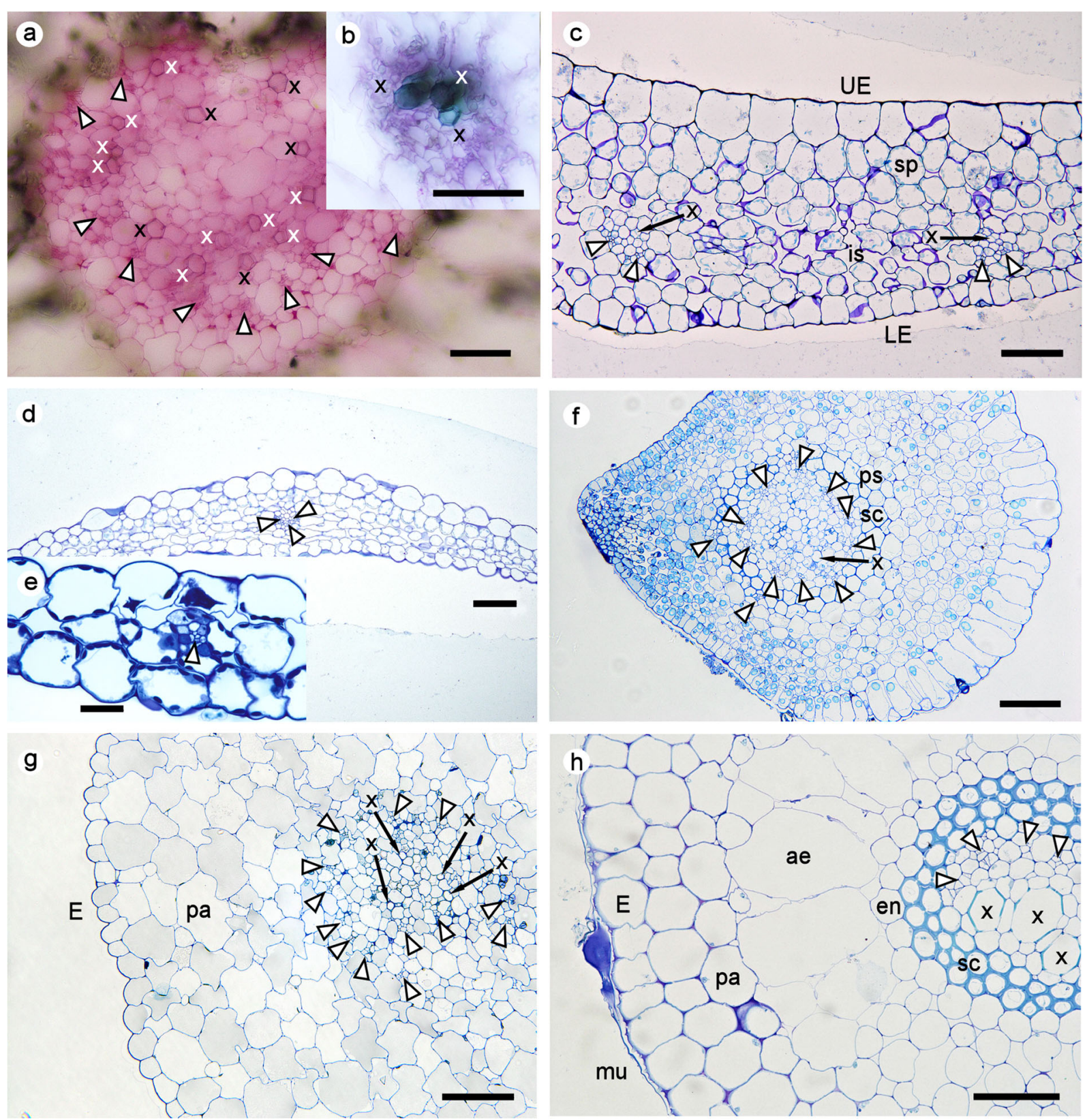

Fig. 1 Cross sections through foliage leaves and stolons of Lentibulariaceae. Main vascular strand of $P$. gigantea with (a) xylem tracheary elements (vessels) (x) arranged in an arc and bordered by phloem (arrowheads) and (b) occasionally grouped together. (c) Genlisea hispidula showing the general anatomy of leaves of Genlisea and Utricularia with upper (UE) and lower (LE) epidermis, spongy parenchyma (sp), intracellular spaces (is), and vascular bundles with xylem tracheary elements and phloem. (d) Vascular bundle in $U$. paulineae with three phloem groups but no visible xylem elements. (e) Leaflet of dissected leaves in the submerged $U$. stygia containing chloroplasts in single layered parenchyma and epidermal cells. In the vascular bundle, only

phloem but no xylem is apparent. (f) Runner stolon of G. repens exhibiting abundant amyloplasts and an ectophloic central cylinder within a sclerenchyma ring (sc), surrounded by a parenchyma sheath (ps). (g) Runner stolon of $P$. gigantea showing a uniseriate epidermis (E), irregularly shaped parenchyma cells (pa) and numerous phloem groups around several vessels in the centre. (h) Main stolon of $U$. tricolor with an epidermis covered by mucilage $\mathrm{(mu}$ ), radially developing lysigenous aerenchyma (ae), and a central cylinder characterized by large vessels and phloem groups and bordered by 2-3 layers of conspicuous sclerenchyma cells within an endodermis (en). Scale bars $=0.1 \mathrm{~mm}$ in $\mathbf{a - d}, \mathbf{f}, \mathbf{g} ; 0.05 \mathrm{~mm}$ in $\mathbf{h}$; $0.02 \mathrm{~mm}$ in $\mathbf{e}$ 
a
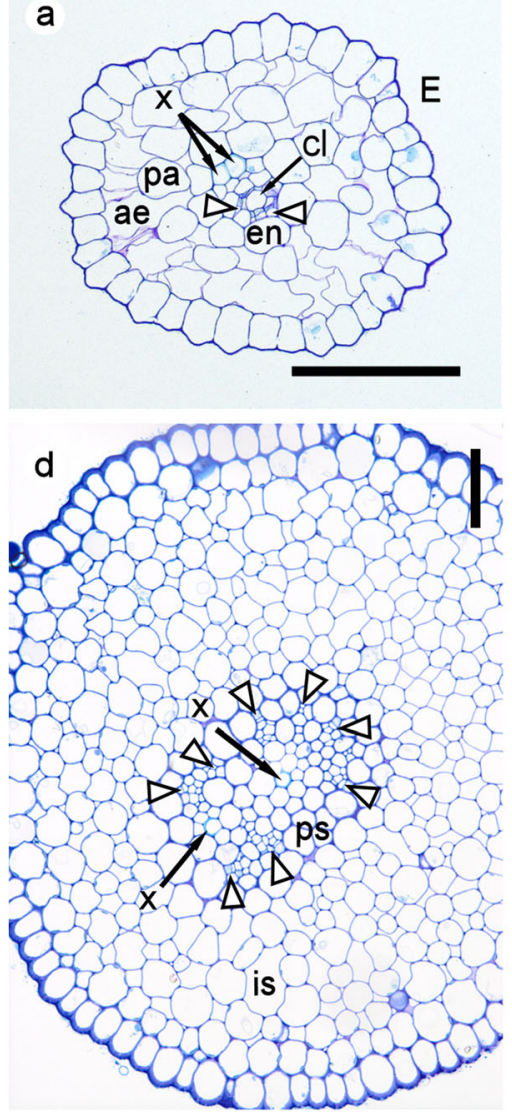

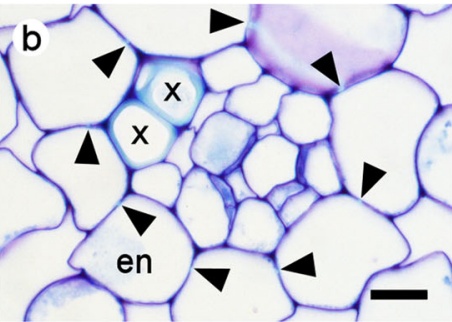

e

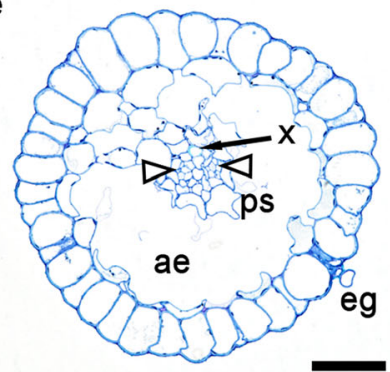

f

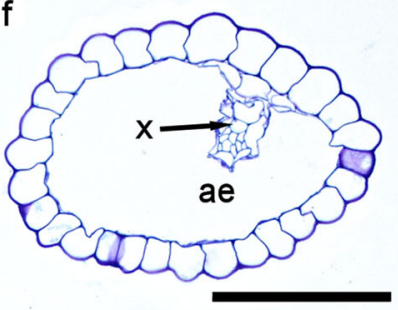

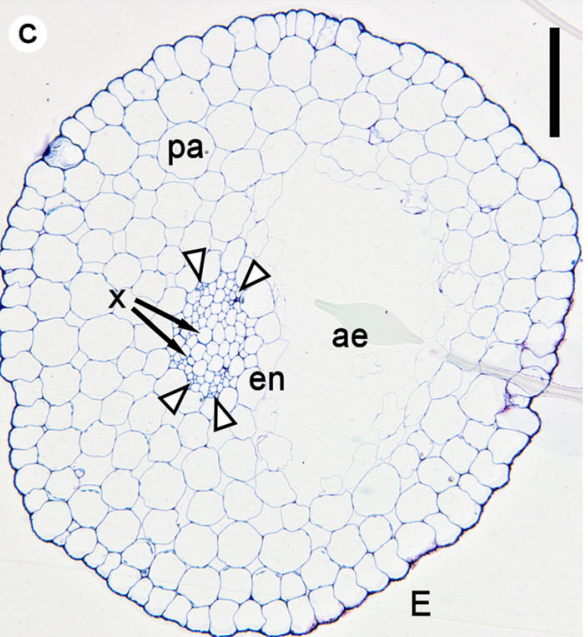

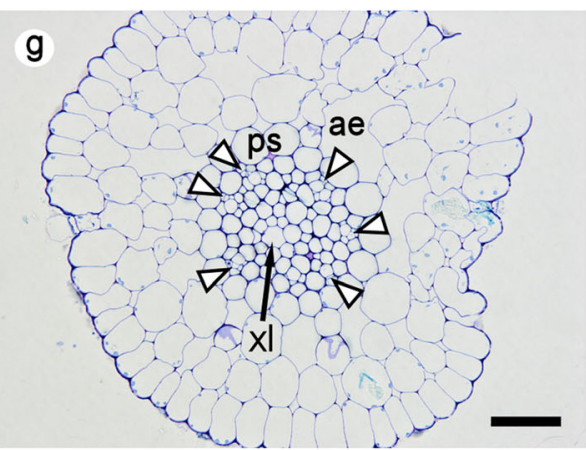

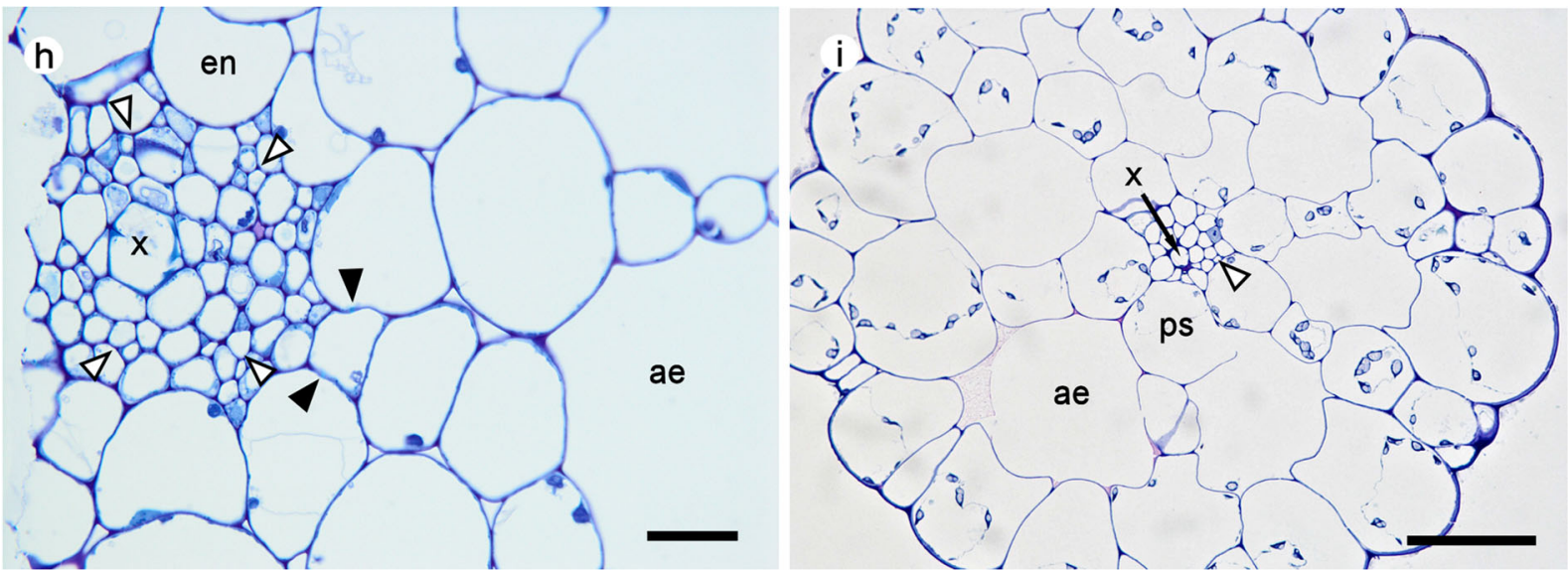

primary branching leading to these clusters were, however, mainly influenced by the two nonmorpho-anatomical traits 'life form' and 'stolon locality' (Table 6). While 'life form' as trait is obviously a bias of life form clustering, 'stolon location' has an affinity to the life form (by the milieu) but also to growth and consequently to morphology. As shown by the biplots (Fig. 3a, c), 'stolon location' correlated to some extent to stolon related traits, namely to 'chloroplast occurrence' and 'xylem diameter', while the contribution of 'occurrence of external glands' was weak (Fig. 3a, c). Hence, in 
Fig. 2 Anatomical structures of stolons of Utricularia. a Main stolon of $U$. delicatula with a uniseriate epidermis (E), aerenchyma (ae) between shrinking parenchyma cells (pa), and an endodermis (en) encompassing a vascular strand with two adjacent xylem tracheary elements $(\mathrm{x})$ and a central lacuna $(\mathrm{cl})$ in a phloem ring (arrowheads). b Close-up of the central cylinder of a, showing lignified Casparian strips (black arrowheads) in the endodermis. c Runner stolon of $U$. oppositiflora with half-moon shaped aerenchyma in one sector, representing a unique distribution, designated as "crescent" pattern. d Main stolon of U. volubilis containing moderate intracellular spaces (is) and a central cylinder with the appearance of a two-part parenchyma sheath (ps), accommodating a double vascular strand with one xylem tracheary element and 4 phloem groups each. e Utricularia dichotoma subsp. aquilonia showing extensive tangentially lysigenous aerenchyma dominating the interior of the runner stolon. f Main stolon of U. uniflora exhibiting an advanced decay of cortex cells, forming 'hollow type' aerenchyma. In the vascular tissue, phloem is indistinct and only one xylem tracheary element is visible. $g$ Main stolon of U. tubulata with schizogenous aerenchyma and a central xylem lacuna (xl) in the vascular strand. Thick-walled cells are abundant within the pith. $\mathbf{h}$ Detailed view into the stele of a main stolon of $U$. stygia revealing an endodermis with Casparian strips encircling the vascular cylinder. i Main stolon of $U$. cucullata showing plastids in the epidermis and in scanty parenchyma. The aerenchyma pattern is wheel-shaped. The vascular bundle exhibits one xylem tracheary element and a sieve tube (arrowhead). Scale bars $=0.1 \mathrm{~mm}$ in $\mathbf{a}, \mathbf{c}, \mathbf{f} ; 0.05 \mathrm{~mm}$ in $\mathbf{d}, \mathbf{e}, \mathbf{g}, \mathbf{i} ; 0.02 \mathrm{~mm}$ in $\mathbf{h}$; $0.01 \mathrm{~mm}$ in $\mathbf{b}$

submerged and free-floating species, main stolons tended to develop chloroplasts in parenchyma and epidermis, and smaller xylem tracheary elements.

The exclusion of the traits 'life form' and 'stolon location' led to a certain decrease of distances of clusters in PCA (compare Fig. 3a, c, d), which became also evident by lower Silhouette Scores (Table 6). The correlation of species was not extremely altered by excluding these traits from the datasets, especially because 'anchoring organ', 'leaf form' and 'leaf thickness' were directly correlated to 'life form' and 'stolon location' and, therefore, likewise contributed to the same (PC1) direction of distribution. In the PCA of all datasets, this approximately horizontal distribution followed a "life form transect" from free-floating to submerged to amphibious species towards the terrestrial $P$. gigantea.

By considering the decisive characters across the PCA of datasets I-III, it appeared that the separation of free-floating and submerged species (with or without $U$. volubilis) from other clusters was strongly influenced by 'stolon location' or 'leaf thickness', and that freefloating species split from submerged species mainly driven by 'anchoring organ' and 'chloroplast occurrence' (Table 6).

The vertical (PC2) distribution was generally related to 'stolon thickness' with some assistance from 'stolon intercellular spaces' (Fig. 3a, c). This was mainly apparent in the amphibious group and reflected in the direction of the corresponding confidence ellipse in Fig. 3d. Being transversal to the horizontal transect, stolon thickness was not correlated to life forms. The vertical scattering of amphibious species represented a gradient of species with thin main stolons containing crescent to hollow aerenchyma (e.g. $U$. uniflora) to species with thick main stolons (e.g. G. repens). However, using graph-based clustering with datasets II and III generated a separation of a group around $U$. delicatula from a diffuse group around $U$. tricolor (Fig. 3b-d; Table 6). The split was diminished when a few theoretical terrestrial species similar to $P$. gigantea were added and 'stolon thickness' was omitted from the datasets. In the PCA scatter plot of the accordingly modified dataset III, $U$. tricolor was much closer to $U$. delicatula, and $U$. oppositiflora was between $U$. dichotoma and $U$. paulineae/U. uniflora (not shown here).

By applying Kernel PCA (KPCA) in dataset II and III, the correlations of species in the datasets differed mainly in the cluster assignment of $U$. volubilis (Table 6), which affiliated with $U$. stygia and the free-floating group or with the terrestrial-amphibious group (Fig. 3b), respectively. When data were pre-processed by unit variance scaling (leading to more or less equally strong traits), the density of clusters was increased and $U$. oppositiflora was much closer to the submerged taxa than to $U$. tricolor (e.g. Fig. 3d vs. a and c).

\section{Discussion}

Morpho-anatomical traits support life form clustering of species in Lentibulariaceae

The applied multivariate analyses show that life form clustering is acceptably supported by adding some terrestrial species and discarding the interfering character 'stolon thickness', even though the submerged group ( $U$. stygia, $U$. volubilis) tends to overlap with the free-floating and/or the amphibious group. The 
Table 6 Cluster analyses of datasets

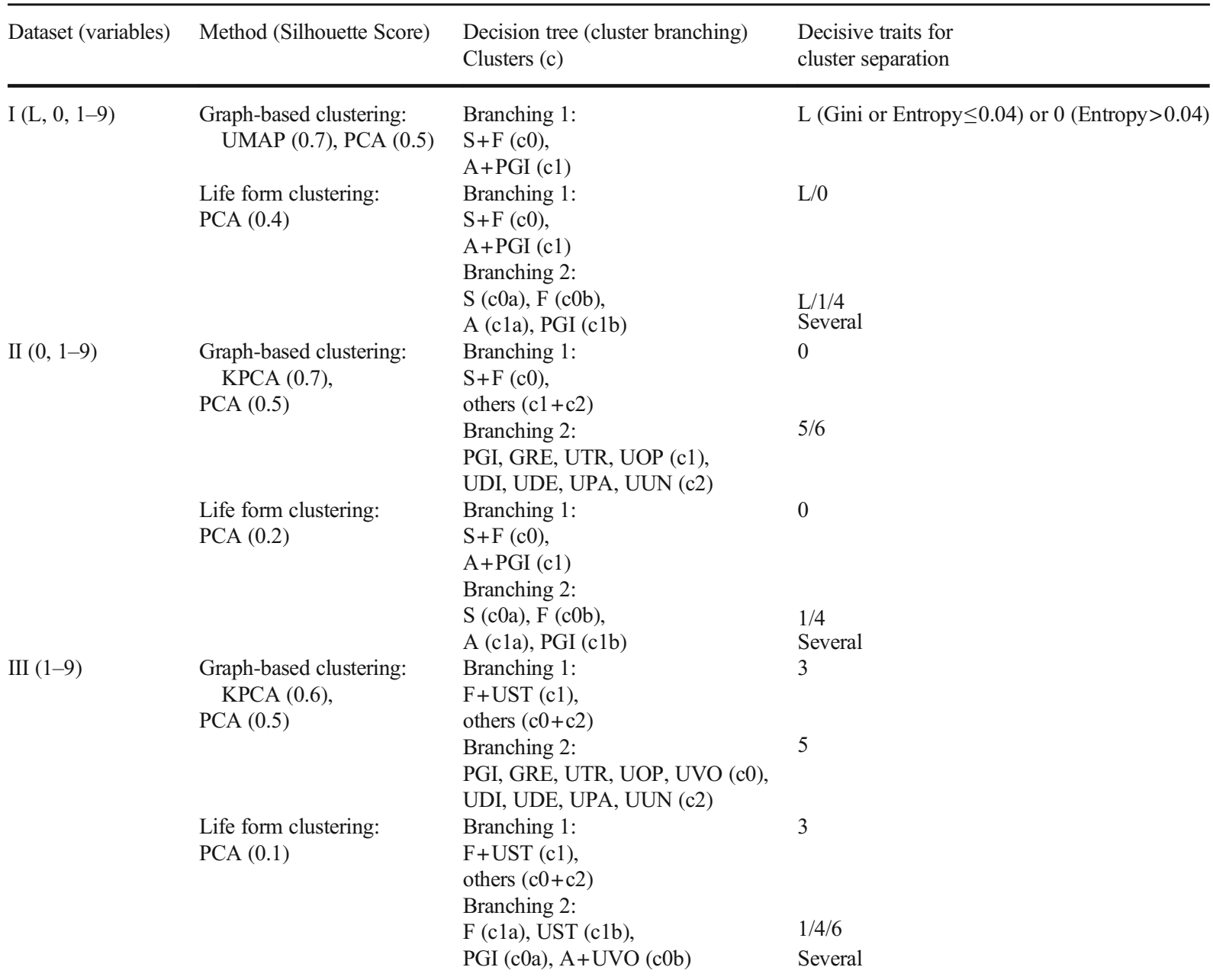

Abbreviations: Kernel PCA (KPCA); Uniform Manifold Approximation and Projection (UMAP); Principal Components Analysis (PCA) Species: G. repens (GRE); P. gigantea (PGI); U. delicatula (UDE); U. dichotoma (UDI); U. oppositiflora (UOP); U. paulineae (UPA); U. stygia (UST); U. tricolor (UTR); U. uniflora (UUN); U. volubilis (UVO)

Plant groups with the same life forms: amphiphytes (A); free-floating hydrophytes (F); submerged hydrophytes (S)

Clusters after branching, e.g.: $\mathrm{S}+\mathrm{F}(\mathrm{c} 0)=\mathrm{S}$ and $\mathrm{F}$ build together cluster $0 . \mathrm{S}(\mathrm{c} 0 \mathrm{a}), \mathrm{F}(\mathrm{c} 0 \mathrm{~b})=\mathrm{S}$ and $\mathrm{F}$ are two subclusters (a and $\mathrm{b}$ ) of cluster 0 Decisive traits (further defined in Table 3): Life form (habit) (L), stolon location (0), anchoring organ (1), leaf thickness (3), stolon chloroplasts (4), stolon diameter (5), and stolon xylem (vessels / diameter) (6)

Traits, e.g.: $1 / 4=$ traits 1 and 4 are more or less interchangeably decisive on the branching

datasets do not contain any emergent species. However, $U$. volubilis and $U$. oppositiflora occur as emergent hydrophytes in some natural habitats (Taylor 1989; Jobson and Baleiero 2020). As expected, both species show a strong correlation and have affinities with the amphibious as well as with the submerged habit.

\section{Leaf traits}

Our results demonstrate that leaves tend to be thinner and narrower from terrestrial to free-floating taxa. On one end of the transect, the anatomy of the fleshy $P$. gigantea leaf is largely consistent with the succulent leaves of several Mexican Pinguicula species of 

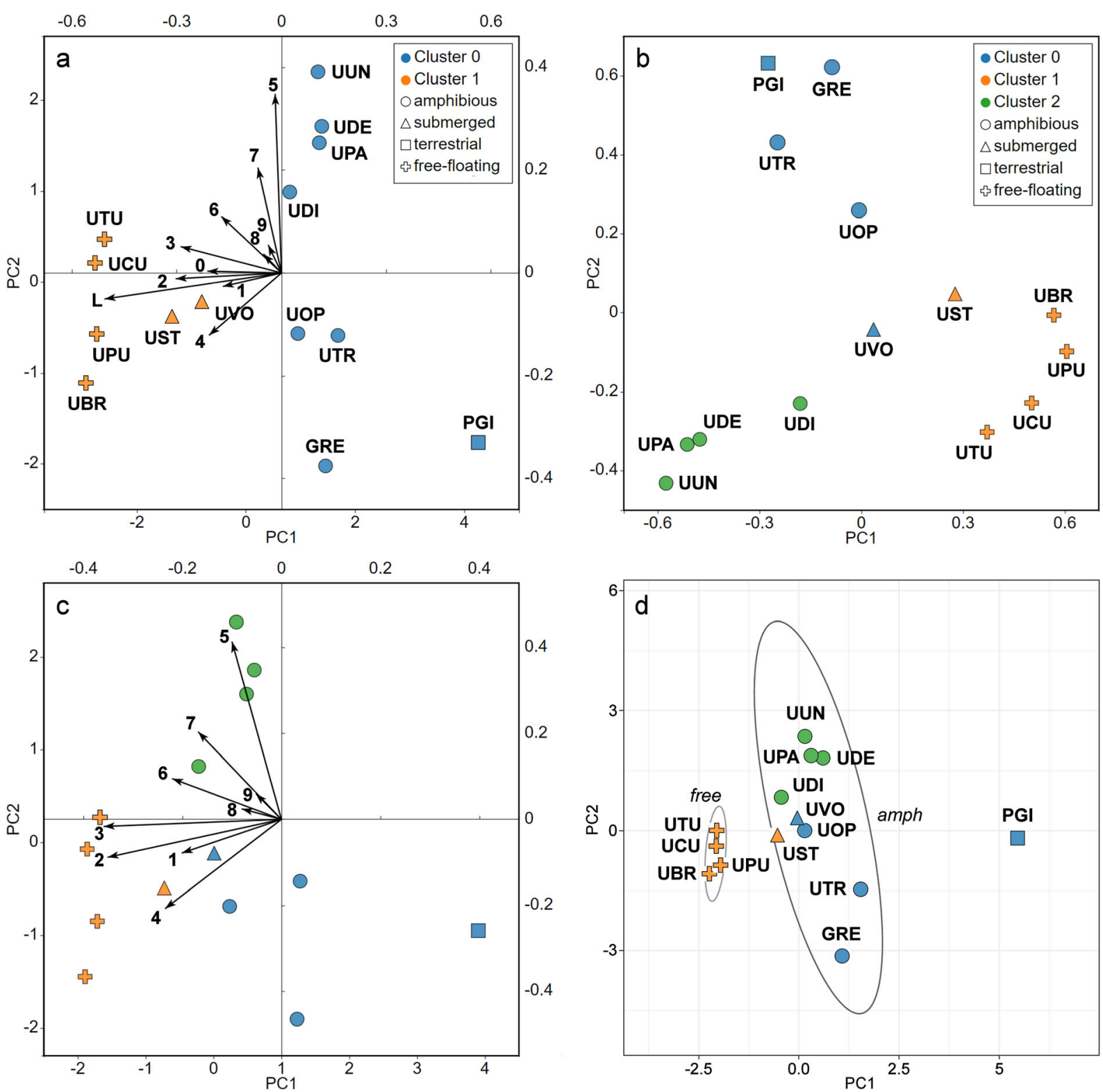

Fig. 3 Visualization of multivariate analyses with graph-based clustering of stoloniferous Lentibulariaceae species. a PCA biplot of dataset I, showing two clearly separated clusters. The submerged UST and UVO are between amphibious and freefloating species. Variances $\mathrm{PC} 1=58.71 \%, \mathrm{PC} 2=20.01 \%$, PC1$3=86.4 \%$. b Scatter plot of species according to KPCA (best fit) of dataset III with three clusters. c PCA biplot of dataset III with the same clusters as in b. $\mathrm{PC} 1=44.38 \%, \mathrm{PC} 2=28.30 \%$, PC1$3=82.64 \%$. d PCA scatter plot of dataset II with unit-variance scaling as pre-processing. Amphiphytes ( hydrophytes (free) are circumscribed by confidence (prediction) ellipses $(\mathrm{CI}=95 \%)$. Both submerged species are imbedded in the

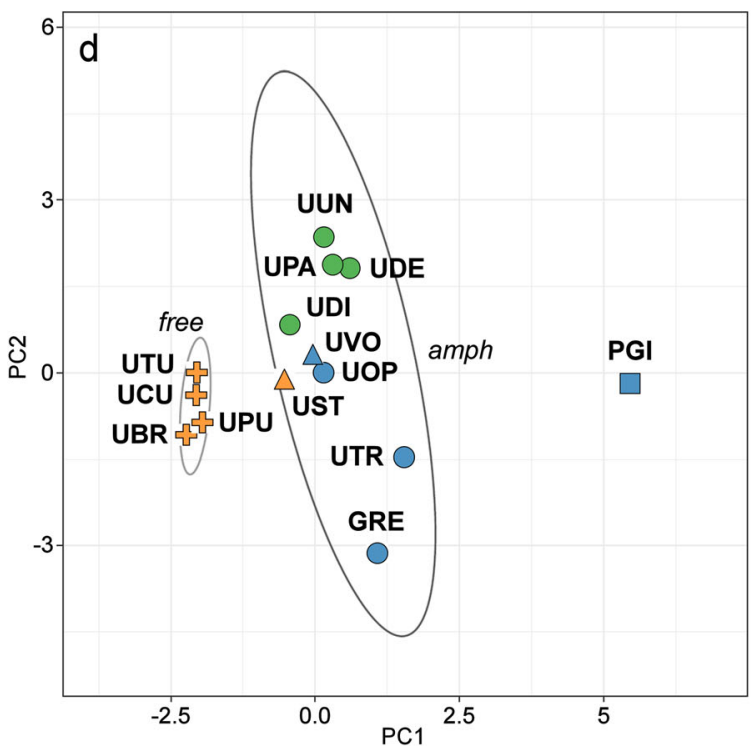

amphibious group. $\mathrm{PC} 1=47.89 \%, \mathrm{PC} 2=21.00 \%, \mathrm{PC} 1-3=$ $82.61 \%$. No scaling was applied to analyses a-c. Species: G. repens (GRE); P. gigantea (PGI); U. breviscapa (UBR); U. cucullata (UCU); U. delicatula (UDE); U. dichotoma subsp. aquilonia (UDI); U. oppositiflora (UOP); U. paulineae (UPA); U. purpurea (UPU); U. stygia (UST); U. tricolor (UTR); U. tubulata (UTU); U. uniflora (UUN); U. volubilis (UVO). Traits (vectors, further defined in Table 3): Life form (habit) (L), stolon location (0), anchoring organ (1), leaf form (2), leaf thickness (3), stolon chloroplasts (4), stolon diameter (5), and stolon xylem (vessels / diameter) (6), stolon intercellular spaces (7), stolon external glands (8), stolon supporting tissue (9) 
subgenera Isoloba and Pinguicula that occupy wet and periodically dry habitats and may use $\mathrm{C}_{4}$ carbon fixation (cf. Studnička 1991). On the other end, in line with e.g. Sculthorpe (1967) and Colmer et al. (2011), our observations on Lentibulariaceae confirm that obligate hydrophytes differ distinctively from emergent, amphibious or terrestrial herbaceous plants by having thin leaves.

Free-floating aquatics are limited to sections Utricularia and Vesiculina (both of subgenus Utricularia) and $U$. tubulata of subgenus Polypompholyx (Taylor 1989). The two former sections carry leaves (if present) divided into capillary segments, whilst the morphologically unique $U$. tubulata shows verticillate and undivided leaves (Taylor 1989), reminding of e.g. the submerged and freely suspended Hydrilla verticillata (cf. Yeo et al. 1984) or the carnivorous free-floatingAldrovanda vesiculosa with terminal traps on its leaves (cf. Adamec 2018). A combination of dissected leaves and a verticillate phyllotaxy is known from e.g. the free-floating (rarely submerged) Ceratophyllum, which is also considered to be rootless (Sculthorpe 1967; Cook 1999).

Our results corroborate that narrow and thin leaves are common features in amphibious and emergent plants as adaptive response to submergence, as shown in e.g. Rumex palustris (Mommer et al. 2005) and Melaleuca cajuputi (Tanaka et al. 2011). In the aquatic environment, the absorption of light and dissolved gases is enhanced by an increased surface area to volume ratio, which is accomplished by thinner, lobed, and dissected leaves (e.g. Sculthorpe 1967; Colmer et al. 2011).

\section{Chlorophyllous tissues}

In accordance with our results, simple anatomical structures without a palisade layer are a common characteristic of submerged leaves (e.g. Wiegleb 1991; Catian and Scremin-Dias 2015; Krähmer 2016), indicating organ flexibility and/or reduced light conditions (cf. Sculthorpe 1967; Gotoh et al. 2018). A diminished photosynthesis rate is partly compensated by chloroplasts occurring in both parenchymatic and epidermal cells of submersed organs (Catian and ScreminDias2015), as indicated in our study by e.g. U. stygia and $U$. cucullata. Results of our multivariate analyses corroborate that aquatic life forms relate to a higher abundance of chloroplasts in tissues of submerged runner stolons (cf. Sculthorpe 1967; Wetzel 1988; Colmer et al. 2011). However, responding to (periodic) submergence or shady habitats, chloroplasts are occasionally observed in the epidermis of leaves (Genlisea sp.; Lang 1901) or in runner stolons (e.g. G. repens) of amphibious species, although in G. repens, plastids may develop into amyloplasts under drier conditions. In Pinguicula, the absence of a chloroplast-rich palisade parenchyma may provide more flexibility to the leaf for carnivorous mechanisms (Heslop-Harrison 2004).

Anchoring organs

In the Lentibulariaceae, Pinguicula still shows "typical" roots (although partly reduced in some species such as P. gigantea). In Utricularia, "rhizoids" (anchor stolons) seem to take on the anchoring function from roots. Our analyses show that the presence/absence of anchor stolons is a delimitation between submerged and freefloating life forms in Utricularia. However, the base of peduncles in some suspended Utricularia species (e.g. U. australis, U. gibba) develop rhizoids (Taylor 1989), which may anchor the plant when flowering.

Structures of absorption and secretion

In the absence of an effective root system, the surfaces of other organs adopt the uptake of water and nutrients (cf. Schenck 1886; Adlassnig et al. 2005; Babourina and Rengel 2010). As in most submerged hydrophytes, the cuticle of organs of the examined species seems to be generally thin, since the mechanical protection is of less importance in the water. On the outer surface of all vegetative organs across the examined Genlisea and Utricularia species, we found numerous button-like trichomes, which were considered being hydropotes (Lloyd 1942; Płachno et al. 2005) with absorptive and/ or secretory function, depending on their ontogeny (Fineran 1980). On traps of Utricularia and Genlisea, mature external glands seem to expel water to the substrate (Fineran 1985; Fineran and Reut unpublished data), while some glandular trichomes on leaves and subterranean organs of Genlisea and Utricularia produce mucilage, e.g. to protect from drying, as defensive compound against herbivores, as source of nutrients for micro-organisms, or as lubricant for penetrating the soil (cf. Lang 1901; Płachno et al. 2005; Rivadavia et al. 2013). Since only Pinguicula lacks external bottom-like trichomes on vegetative organs, the occurrence of these glands does only marginally contribute to the life form clustering in the present study. 
Further histochemical and ultrastructural work (including tracers) on the epidermis, cuticle, and external glands of Genlisea and Utricularia of various habits would be helpful to increase the knowledge on permeability and the various functions of external glands in relation to their position on the organ and their developmental stages.

\section{Conductive tissues}

A general simplification of xylem tissue in subterranean and submersed organs was evident in the species studied. However, in the aquatic environment, the reduction of xylem and lignified elements does not necessarily impede the acropetal flow of water and nutrients (Sculthorpe 1967; Pedersen and Sand-Jensen1993; Lusa et al. 2011). Moreover, in some main stolons of Utricularia, we were able to identify an endodermis with Casparian strips (CS), which directs and controls the passage of water and minerals (cf. Barberon 2017). Although an endodermis with CS mainly occurs in roots, it is not uncommon in aerial shoots and leaves (Lersten 1997; Seago 2020) but more often established in subterranean or submersed stems (Dalla Vecchia et al. 1999). In the "rootless" bladderworts, the conductive function of the endodermis has been seemingly transferred from roots into stolons that manifest dynamic developmental processes for roots, shoots, and leaves (Rutishauser 2016, 2020; Reut and Płachno 2020).

Due to the thin cell walls of the parenchyma sheaths, the capability to visualize the CS was limited. Therefore, even if the CS could not be detected, the presence of CS cannot be conclusively ruled out for the remaining species of the study. Other staining and fluorescence techniques should be applied to improve the identification of $\mathrm{CS}$ and to gain insights into their composition (see e.g. Dalla Vecchia et al. 1999; Naseera et al. 2012; Seago 2020).

\section{Aerenchyma}

To enhance the exchange of gases within and between roots, stems, and leaves, plants develop intercellular cavities or chambers of various sizes (Takahashi et al. 2014), whereby the enlarged space is called 'aerenchyma' (Seago et al. 2005; Jung et al. 2008), which additionally facilitates buoyancy (Krähmer 2016). Although aerenchyma is typical for hydrophytes, it is also known from some terrestrial plants caused by several forms of stress (Evans 2003; Jung et al. 2008). The morphoanatomical differences between emergent and submerged taxa studied reflect a big step from slight or periodic inundation to complete and permanent submergence. Colonization of habitats with standing water (e.g. swamps, pools, lakes) has evolved with the abundance of large air cavities in submerged organs, supporting an efficient diffusion of gases (cf. Wetzel 1988).

Lysigenous aerenchyma results from programmed cell death and cell collapse, which can be induced by hypoxia, nutrient deficiency and/or ethylene accumulation (Evans 2003; Striker 2012). Since lysigenous aerenchyma formation is dominant in the material studied, these factors may all be present in the preferred habitats of Genlisea and Utricularia, in which their carnivorous strategy (partly) compensates the limited availability of certain nutrients (cf. Adamec 1997). Lysigenous aerenchyma was also reported by Schweingruber et al. (2020) from stems of submerged Utricularia species and the carnivorous free-floatingAldrovanda vesiculosa.

Our results indicate that the 'wheel-shaped' aerenchyma pattern is abundant in main stolons of submerged and free-floatingUtricularia species, which is supported by earlier observations on shoots of $U$. tenuicaulis (syn. $U$. australis) and $U$. gibba of section Utricularia by Jung et al. (2008) and Chormanski and Richards (2012), respectively. Within the same order Lamiales, it was reported from the submerged Limnophila sessiflora by Jung et al. (2008).

The unique 'crescent' type aerenchyma, observed in runner stolons of $U$. oppositiflora, seems to be due to the dorsiventral symmetry of these stolons with organs arising on nodes on the upper side of the runner (cf. Reut and Płachno 2020). The continuing decay of parenchymatic cells (seemingly by tangential lysigeny) leads to a special 'hollow type' aerenchyma, which is evident in several subterranean organs of the examined amphibious species of Genlisea (see also Lloyd 1942) and Utricularia subg. Polypompholyx.

Schizogeny, as visible in main stolons of $U$. volubilis and U. tubulata of section Pleiochasia, is developed by cell differentiation, but molecular mechanisms substantial for this formation type are not yet known (Yamauchi et al. 2018).

\section{Supporting tissues}

Our results confirm earlier observations on Genlisea (Merl 1915) and Utricularia (Schenck 1886; Kamieński 
1891), whereupon the anatomy of thicker stems is characterized by a central cylinder and by an increasing number of vascular elements and the occurrence of supporting tissue, as indicated by sclerenchyma around the pith in runner stolons of G. repens and U. tricolor. Sclerenchyma was also reported below the epidermis of adhesive anchor stolons of the rheophytic $U$. neottioides by Płachno et al. (2020a). However, since only two amphibious species in our dataset showed sclerenchyma around the pith in runner stolons, this trait did not contribute greatly to the delimitation of life forms in the multivariate analyses.

\section{Evolutionary aspects of the Lentibulariaceae}

With respect to the morpho-anatomical features, our findings reveal that the reduction of roots and conductive tissues (especially xylem) are taxonomically common characteristics of all genera of the Lentibulariaceae, which points to an ancestor that was adapted to at least seasonally wet and/or periodically inundated habitats. The more free water is abundant, the less protection and stability of organs is required, which is apparently reflected in a loss of the root cap in some Pinguicula species (cf. Rutishauser 2016, 2020), the palisade layer in leaves, and supporting tissues in subterranean/ submersed organs within the Lentibulariaceae.

Apart from an abandonment of several developmental processes for roots, Genlisea and Utricularia share other more hydrophilic features, such as (in general) more delicate organs with reduced cuticle and buttonlike glandular trichomes on the surface of leaves and subterranean/submersed organs, indicating a next level in the adaptation to submergence but also a shift of the carnivory from aerial leaves (in Pinguicula) to underground leaf-like organs (in Genlisea-Utricularia). In other words, costs for innovative structures used for the uptake of nutrients are compensated by less investment in other structures (e.g. cortex, vascular elements and supporting tissue), which seems to be facilitated in a watery milieu.

Most of the plants in our study were kept ex situ in their preferred conditions, and hence revealed more adaptive rather than reactive morpho-anatomical features. We recommend that future research on hydrophytes with a comparable plasticity takes the differentiation of emergent and submerged life forms into consideration. An experimental approach with variable settings (e.g. water levels, light) could unlock which morpho-anatomical changes are adaptations and which ones are responses.

Morpho-anatomical and functional adaptations to a life between land and water

The key findings of our study are:

- Life forms along the hydric transect in the Lentibulariaceae correlate directly to the location of the stolon in the substrate and to the shape and thickness of leaves, which aims at enhancing the absorption of sparse light, nutrients, dissolved gases as well as the flexibility of leaves with increasing depth of submergence of vegetative organs.

- Submerged and free-floatingUtricularia species tend to develop chloroplasts in parenchymatic and epidermal cells of suspended main stolons, which supports the collection of light.

- Life forms in the Lentibulariaceae correspond with the reduction of the typical root morphology and with the presence and type of anchorage.

- Buoyancy and gas exchange are enhanced by large intercellular cavities that are abundant in stems and shoots of amphibious to free-floating taxa studied. Novel 'crescent' to special 'hollow' aerenchyma patterns develop in dorsiventrally organized stems and shoots of amphibious Genlisea and Utricularia species.

- Morpho-anatomical characters in vegetative organs of Genlisea and Utricularia strongly show adaptations to the hydric environment, which they share with many other aquatic plants. However, some of these features may have been partly driven by the evolutionary shift of carnivory from aerial to subterranean organs and hence by an alternative uptake of certain minerals in nutrient-poor and submerged habitats.

Supplementary Information The online version contains supplementary material available at https://doi.org/10.1007/s11104021-04929-6.

Acknowledgements This research was partially supported financially by the Ministry of Science and Higher Education of Poland as part of the statutory activities of the Department of Plant 
Cytology and Embryology, Institute of Botany, Faculty of Biology, Jagiellonian University in Kraków (N18/DBS/000002). The scientific stay of BJP in Brazil was financed by the Jagiellonian University within the project Integrate JU-Comprehensive Development Programme of the Jagiellonian University as part of the Knowledge Education Development 2014-2020 Operational Programme co-financed by the European Social Fund in the European Union (POWR.03.05.00-00Z309/17-00).

This paper is dedicated to Brian A. Fineran, mentor, friend, excellent taxonomist, and expert in the ultrastructure of Utricularia and parasitic plants, and in good memories of Christopher D. K. Cook, a profound researcher of aquatic plants. We are cordially grateful to Lubomír Adamec (Institute of Botany of the Czech Academy of Sciences, Třeboň, Czech Republic), Kamil Pásek (Best Carnivorous Plants Store, Czech Republic), and Corin Gardiner for material from their collections. We thank the editor and reviewers for their valuable comments and helpful suggestions for the manuscript.

\section{Declarations}

Conflict of interest The authors declare that they have no conflict of interest.

\section{References}

Adamec L (1997) Mineral nutrition of carnivorous plants: a review. Bot Rev 63:273-299. https://doi.org/10.1007 /BF02857953

Adamec L (2018) Biological flora of Central Europe: Aldrovanda vesiculosa L. Perspect Plant Ecol 35:8-21. https://doi. org/10.1016/j.ppees.2018.10.001

Adlassnig W, Peroutka M, Lambers H, Lichtscheidl IK (2005) The roots of carnivorous plants. Plant Soil 274:127-140

Arber A (1920) Water plants. A study of aquatic angiosperms. Cambridge University Press, Cambridge

Babourina O, Rengel Z (2010) Ion transport in aquatic plants. In: Mancuso S, Shabala S (eds) Waterlogging signalling and tolerance in plants. Springer, Berlin, pp 221-238. https://doi.org/10.1007/978-3-642-10305-6_11

Barberon M (2017) The endodermis as a checkpoint for nutrients. New Phytol 213:1604-1610. https://doi.org/10.1111 /nph.14140

Barrett SCH, Eckert CG, Husband CG (1993) Evolutionary processes in aquatic plant populations. Aquat Bot 44:105-145

Braendle R, Crawford RMM (1999) Plants as amphibians. Perspect Plant Ecol 2:56-78

Casper SJ (2019) The insectivorous genus Pinguicula (Lentibulariaceae) in the Greater Antilles. In: Englera 35. Botanic Garden and Botanical Museum Berlin. Freie Universität Berlin, Berlin

Catian G, Scremin-Dias E (2015) Phenotypic variations in leaf anatomy of Nymphaea gardneriana (Nymphaeaceae) demonstrate its adaptive plasticity. J Torrey Bot Soc 142:18-26

Chambers PA, Lacoul P, Murphy KJ, Thomaz SM (2008) Global diversity of aquatic macrophytes in freshwater.
Hydrobiologia 595:9-26. https://doi.org/10.1007/s10750007-9154-6

Chormanski TA, Richards JH (2012) An architectural model for the bladderwort Utricularia gibba (Lentibulariaceae). J Torrey Bot Soc 139:137-148

Cieslak T, Polepalli JS, White A et al (2005) Phylogenetic analysis of 'Pinguicula (Lentibulariaceae): chloroplast DNA sequences and morphology support several geographically distinct radiations. Am J Bot 92:1723-1736. https://doi. org/10.3732/ajb.92.10.1723

Colmer TD, Winkel A, Pedersen O (2011) A perspective on underwater photosynthesis in submerged terrestrial wetland plants. AoB Plants 11:1-15

Cook CDK (1999) The number and kinds of embryo-bearing plants which have become aquatic: a survey. Perspect Plant Ecol 2:79-102

Crawford RMM (2008) Plants at the margin. Ecological limits and climate change. Cambridge University Press, New York

Dalla Vecchia F, Cuccato F, La Rocca N et al (1999) Endodermislike sheaths in the submerged freshwater macrophyte Ranunculus trichophyllus Chaix. Ann Bot 83:93-97

Evans DE (2003) Aerenchyma formation. New Phytol 161:35-49

Fineran BA (1980) Ontogeny of external glands in the bladderwort Utricularia monanthos. Protoplasma 105:9-25

Fineran BA (1985) Glandular trichomes in Utricularia: a review of their structure and function. Israel J Bot 34:295-330. https://doi.org/10.1080/0021213X.1985.10677028

Fleischmann A (2012) Monograph of the genus Genlisea. Redfern Natural History, Poole

Fleischmann A (2018) Systematics and evolution of Lentibulariaceae. II. Genlisea. In: Ellison AM, Adamec L (eds) Carnivorous plants: physiology, ecology, and evolution. Oxford University Press, New York, pp 81-88. https://doi.org/10.1093/oso/9780198779841.003.0007

Fleischmann A, Roccia A (2018) Systematics and evolution of Lentibulariaceae. I. Pinguicula. In: Ellison AM, Adamec L (eds) Carnivorous plants: physiology, ecology, and evolution. Oxford University Press, New York, pp 70-80. https://doi.org/10.1093/oso/9780198779841.003.0006

Gotoh E, Suetsugu N, Higa T et al (2018) Palisade cell shape affects the light-induced chloroplast movements and leaf photosynthesis. Sci Rep 8:1472. https://doi.org/10.1038 /s41598-018-19896-9

Guisande C, Granado-Lorencio C, Andrade-Sossa C, Duque SR (2007) Bladderworts. Funct Plant Sci Biotechnol 1:58-68

Heslop-Harrison Y (2004)Pinguicula L. J Ecol 92:1071-1118

Hidalgo O, Garcia S, Garnatje T et al (2015) Genome size in aquatic and wetland plants: fitting with the large genome constraint hypothesis with a few relevant exceptions. Plant Syst Evol 301:1927-1936. https://doi.org/10.1007/s00606015-1205-2

Humphrey C, Pittman G (1974) A simple methylene blue-azure IIbasic fuchsin for epoxy-embedded tissue sections. Stain Technol 49:9-14

Hutchinson GE (1975) A treatise on limnology. Vol III. Limnological botany. Wiley, New York

Ibarra-Laclette E, Lyons E, Hernández-Guzmán G et al (2013) Architecture and evolution of a minute plant genome. Nature 498:94-98

Jobson RW, Baleeiro PC (2020) Radiations of fairy-aprons (Utricularia dichotoma, Lentibulariaceae) in Australia and 
New Zealand: molecular evidence and proposal of new subspecies. Aust Syst Bot 33:278-310. https://doi.org/10.1071 /SB19003

Jobson RW, Playford J, Cameron KM, Albert VA (2003) Molecular phylogenetics of Lentibulariaceae inferred from plastid $r p s 16$ intron and $t r n$ L-F DNA sequences: implications for character evolution and biogeography. Syst Bot 28:157171

Jobson RW, Baleeiro PC, Guisande C (2018) Systematics and evolution of Lentibulariaceae: III. Utricularia. In: Ellison AM, Adamec L (eds) Carnivorous plants: physiology, ecology, and evolution. Oxford University Press, New York, pp 89104. https://doi.org/10.1093/oso/9780198779841.003.0008

Jung J, Lee SC, Choi H-K (2008) Anatomical patterns of aerenchyma in aquatic and wetland plants. J Plant Biol 51:428439. https://doi.org/10.1007/BF03036065

Kamieński F (1891) Lentibulariaceae. In: Engler A, Prantl KAE (eds) Die Natürlichen Pflanzenfamilien. Part IV, 3b. W. Engelmann, Leipzig, pp 108-123

Krähmer H (2016) Aquatic and wetland weeds. In: Krähmer H (ed) Atlas of weed mapping. Wiley-Blackwell, Chichester, pp 185-400

Lang FX (1901) ) Untersuchungen über Morphologie, Anatomie und Samenentwicklung von Polypompholyx und Byblis gigantea. Flora 88:149-206

Legendre L (2000) The genus Pinguicula L. (Lentibulariaceae): an overview. Acta Bot Gallica 147:77-95. https://doi. org/10.1080/12538078.2000.10515837

Lersten NR (1997) Occurrence of endodermis with a Casparian strip in stem and leaf. Bot Rev 63:265-272

Li G, Hu S, Hou H, Kimura S (2019) Heterophylly: phenotypic plasticity of leaf shape in aquatic and amphibious plants. Plants 8:420. https://doi.org/10.3390/plants8100420

Lloyd FE (1942) The carnivorous plants. Chronica Botanica Company, Waltham

Lusa MG, Torres Boeger MR, de Chiara Moço MC, Bona C (2011) Morpho-anatomical adaptations of Potamogeton polygonus (Potamogetonaceae) to lotic and lentic environments. Rodriguésia 62:927-936

Lustofin K, Świątek P, Miranda VFO, Płachno BJ (2020) Flower nectar trichome structure of carnivorous plants from the genus butterworts Pinguicula L. (Lentibulariaceae). Protoplasma 257:245-259. https://doi.org/10.1007/s00709019-01433-8

Merl EM (1915) Beiträge zur Kenntnis der Utricularien und Genliseen. Flora 108:127-200

Metsalu T, Vilo J (2015) Clustvis: a web tool for visualizing clustering of multivariate data using principal component analysis and heatmap. Nucleic Acids Res 43:W566-W570. https://doi.org/10.1093/nar/gkv468

Mommer L, Pons TL, Wolters-Arts M et al (2005) Submergenceinduced morphological, anatomical, and biochemical responses in a terrestrial species affect gas diffusion resistance and photosynthetic performance. Plant Physiol 139:497-508

Naseera S, Leea Y, Lapierreb C et al (2012) Casparian strip diffusion barrier in Arabidopsis is made of a lignin polymer without suberin. Proc Natl Acad Sci USA 109:10101-10106. https://doi.org/10.1073/pnas.1205726109

Pedersen O, Sand-Jensen K (1993) Water transport in submerged macrophytes. Aquat Bot 44:385-406
Płachno BJ, Jankun A (2004) Transfer cell wall architecture in secretory hairs of Utricularia intermedia traps. Acta Biol Cracov Bot 46:193-200

Płachno BJ, Muravnik LE (2018) Functional anatomy of carnivorous traps. In: Ellison AM, Adamec L (eds) Carnivorous plants: physiology, ecology, and evolution. Oxford University Press, New York, pp 167-179. https://doi. org/10.1093/oso/9780198779841.001.0001

Płachno BJ, Faber J, Jankun A (2005) Cuticular discontinuities in glandular hairs of Genlisea St.-Hil. in relation to their functions. Acta Bot Gallica 152:125-130. https://doi.org/10.1080 $/ 12538078.2005 .10515463$

Płachno BJ, Adamec L, Kamińska I (2014) Relationship between trap anatomy and function in Australian carnivorous bladderworts (Utricularia) of the subgenus Polypompholyx. Aquat Bot 120:290-296

Płachno BJ, Kamińska I, Adamec L, Świątek P (2017) Vascular tissue in traps of Australian carnivorous bladderworts (Utricularia) of the subgenus Polypompholyx. Aquat Bot 142:25-31

Płachno BJ, Świątek P, Adamec L et al (2019a) The trap architecture of Utricularia multifida and Utricularia westonii (subg. Polypompholyx). Front Plant Sci 10:336. https://doi. org/10.3389/fpls.2019.00336

Płachno BJ, Świątek P, Miranda VFO et al (2019b) The structure and occurrence of a velum in Utricularia traps (Lentibulariaceae). Front Plant Sci 10:302. https://doi. org/10.3389/fpls.2019.00302

Płachno BJ, Adamec L, Świątek P et al (2020a) Life in the current: Anatomy and Morphology of Utricularia neottioides. Int $\mathrm{J}$ Mol Sci 21:4474. https://doi.org/10.3390/ijms21124474

Płachno BJ, Silva SR, Świątek P et al (2020b) Structural features of carnivorous plant (Genlisea, Utricularia) tubers as abiotic stress resistance organs. J Mol Sci 21:5143. https://doi. org/10.3390/ijms21145143

Reut MS (1993) ) Trap structure of the carnivorous plant Genlisea (Lentibulariaceae). Bot Helv 103:101-111

Reut MS, Płachno BJ (2020) Unusual developmental morphology and anatomy of vegetative organs in Utricularia dichotoma-leaf, shoot and root dynamics. Protoplasma 257:371-390. https://doi.org/10.1007/s00709-019-01443-6

Rivadavia F, Gonella PM, Fleischmann A (2013) A new and tuberous species of Genlisea (Lentibulariaceae) from the Campos Rupestres of Brazil. Syst Bot 38:464-470. https://doi.org/10.1600/036364413X666679

Rutishauser R (2016) Evolution of unusual morphologies in Lentibulariaceae (bladderworts and allies) and Podostemaceae (river-weeds): a pictorial report at the interface of developmental biology and morphological diversification. Ann Bot 117:811-832. https://doi.org/10.1093 /aob/mcv172

Rutishauser R (2020) EvoDevo: Past and future of continuum and process plant morphology. Philosophies 5:41. https://doi. org/10.3390/philosophies5040041

Schenck H (1886) Vergleichende Anatomie der submersen Gewächse. Theodor Fischer, Cassel

Schweingruber F, Kučerová A, Adamec L, Doležal J (2020) Anatomic atlas of aquatic and wetland plant stems. Springer, Cham. https://doi.org/10.1007/978-3-030-33420-8

Sculthorpe CD (1967) The biology of aquatic vascular plants. Edward Arnold Ltd., London 
Seago JL Jr (2020) Revisiting the occurrence and evidence of endodermis in angiosperm shoots. Flora 273(2020):151709. https://doi.org/10.1016/j.flora.2020.151709

Seago JL Jr, Leland C, Marsh LC et al (2005) A re-examination of the root cortex in wetland flowering plants with respect to aerenchyma. Ann Bot 96:565-579

Silva SR, Moraes AP, Penha HA et al (2020a) The terrestrial carnivorous plant Utricularia reniformis sheds light on environmental and life-form genome plasticity. Int J Mol Sci 21: 3. https://doi.org/10.3390/ijms21010003

Silva RS, Płachno BJ, Carvalho SGM, Miranda VFO (2020)Genlisea hawkingii (Lentibulariaceae), a new species from Serra da Canastra, Minas Gerais, Brazil. PLoS One 15: e0226337. https://doi.org/10.1371/journal.pone.0226337

Striker GG (2012) Flooding stress on plants: anatomical, morphological and physiological responses. Botany 1:3-28

Studnička M (1991) Interesting succulent features in the Pinguicula species from the Mexican evolutionary centre. Folia Geobot Phytotaxon 26:459-462

Takahashi H, Yamauchi T, Colmer T, Nakazono M (2014) Aerenchyma formation in plants. Plant Cell Monogr 21: 247-265

Tanaka K, Masumori M, Yamanoshita T, Tange T (2011) Morphological and anatomical changes of Melaleuca cajuputi under submergence. Trees 25:695-704. https://doi. org/10.1007/s00468-011-0547-9
Taylor P (1989) The genus Utricularia: a taxonomic monograph. HMSO, London

Tiner RW (2017) Wetland indicators: a guide to wetland identification, delineation, classification, and mapping. CRC Press, Boca Raton. https://doi.org/10.1201/9781420048612

Wetzel RG (1988) Water as an environment for plant life. In: Symoens J-J (ed) Vegetation of inland waters. Kluwer, Dordrecht, pp 1-30

Wiegleb G (1991) Die Lebens- und Wuchsformen der makrophytischen Wasserpflanzen und deren Beziehungen zur Ökologie, Verbreitung und Vergesellschaftung der Arten. Tuexenia 11:135-147

Yamauchi T, Colmer TD, Pedersen O, Nakazonoa M (2018) ) Regulation of root traits for internal aeration and tolerance to soil waterlogging-flooding stress. Plant Physiol 176:11181130

Yeo RR, Falk RH, Thurston JR (1984) The morphology of Hydrilla (Hydrilla verticillata (L. f.) Royle). J Aquat Plant Manage 22:1-17

Publisher's note Springer Nature remains neutral with regard to jurisdictional claims in published maps and institutional affiliations. 